\title{
Bariatric surgery can acutely modulate ER-stress and inflammation on subcutaneous adipose tissue in non-diabetic patients with obesity
}

\author{
Rafael Ferraz-Bannitz ${ }^{1 *}$, Caroline Rossi Welendorf ${ }^{1}$, Priscila Oliveira Coelho ${ }^{1}$, Wilson Salgado $\mathrm{rr}^{2}$, \\ Carla Barbosa Nonino ${ }^{3}$, Rebeca A. Beraldo ${ }^{1}$ and Maria Cristina Foss-Freitas ${ }^{1 *}$
}

\begin{abstract}
Background: Bariatric surgery, especially Roux-en-Y gastric bypass (RYGB), is the most effective and durable treatment option for severe obesity. The mechanisms involving adipose tissue may be important to explain the effects of surgery.

Methods: We aimed to identify the genetic signatures of adipose tissue in patients undergoing RYGB. We evaluated 13 obese, non-diabetic patients (mean age 37 years, 100\% women, Body mass index (BMI) $42.2 \mathrm{~kg} / \mathrm{m}^{2}$ ) one day before surgery, 3 and 6 months (M) after RYGB.

Results: Analysis of gene expression in adipose tissue collected at surgery compared with samples collected at $3 \mathrm{M}$ and 6 M Post-RYGB showed that interleukins [Interleukin 6, Tumor necrosis factor-a (TNF-a), and Monocyte chemoattractant protein-1 (MCP1)] and endoplasmic reticulum stress (ERS) genes [Eukaryotic translation initiation factor 2 alpha kinase 3 (EIF2AK3) and Calreticulin (CALR)] decreased during the follow-up ( $P \leq 0.01$ for all). Otherwise, genes involved in energy homeostasis [Adiponectin and AMP-activated protein kinase (AMPK)], cellular response to oxidative stress [Sirtuin 1, Sirtuin 3, and Nuclear factor erythroid 2-related factor 2 (NRF2)], mitochondrial biogenesis [Peroxisome proliferator-activated receptor gamma coactivator 1-alpha (PGC1a)] and amino acids metabolism [General control nonderepressible 2 (GCN2)] increased from baseline to all other time points evaluated ( $\leq 0.01$ for all). Also, expression of Peroxisome proliferator-activated receptor gamma (PPART) (adipogenesis regulation) was significantly decreased after RYGB $(P<0.05)$. Additionally, we observed that PGC1a, SIRT1 and AMPK strongly correlated to BMI at $3 \mathrm{M}(\mathrm{P} \leq 0.01$ for all), as well as ADIPOQ and SIRT1 to BMI at $6 \mathrm{M}(\mathrm{P} \leq 0.01$ for all).

Conclusions: Our findings demonstrate that weight loss is associated with amelioration of inflammation and ERS and increased protection against oxidative stress in adipose tissue. These observations are strongly correlated with a decrease in BMI and essential genes that control cellular energy homeostasis, suggesting an adaptive process on a gene expression level during the caloric restriction and weight loss period after RYGB.

Trial registration CAAE: $73,585,317.0 .0000 .5440$
\end{abstract}

\footnotetext{
*Correspondence: ferrazrafael@usp.br; crisfoss@fmrp.usp.br

${ }^{1}$ Division of Endocrinology and Metabolism, Department of Internal Medicine, Ribeirao Preto Medical School, University of Sao Paulo (USP), Avenida Bandeirantes, 3900-Vila Monte Alegre, Ribeirao Preto, SP 14049-900, Brazil

Full list of author information is available at the end of the article
}

c) The Author(s) 2021. This article is licensed under a Creative Commons Attribution 4.0 International License, which permits use, sharing, adaptation, distribution and reproduction in any medium or format, as long as you give appropriate credit to the original author(s) and the source, provide a link to the Creative Commons licence, and indicate if changes were made. The images or other third party material in this article are included in the article's Creative Commons licence, unless indicated otherwise in a credit line to the material. If material is not included in the article's Creative Commons licence and your intended use is not permitted by statutory regulation or exceeds the permitted use, you will need to obtain permission directly from the copyright holder. To view a copy of this licence, visit http://creativeco mmons.org/licenses/by/4.0/. The Creative Commons Public Domain Dedication waiver (http://creativecommons.org/publicdomain/ zero/1.0/) applies to the data made available in this article, unless otherwise stated in a credit line to the data. 
Keywords: Obesity, Bariatric surgery, Roux-en-Y gastric bypass, Human adipose tissue, Endoplasmic reticulum stress, Oxidative stress, Inflammation

\section{Background}

Obesity is recognized as one of the leading global health problems, and its management is a significant challenge for health services due to its relationship with metabolic complications, including Type 2 Diabetes (T2D), cardiovascular diseases and several types of cancer [1-4].

Currently, bariatric surgery is considered the best treatment for sustained weight loss and reduced comorbidities associated with obesity [5]. Especially Roux-en$\mathrm{Y}$ gastric bypass (RYGB) is considered one of the most effective procedures, promoting both weight reduction and improvement of metabolism [5, 6]. The mechanisms underlying the remarkable effects induced by RYGB in decreasing body weight in controlling T2D and cardiovascular diseases remain uncertain. Some studies suggest that postoperative caloric restriction is sufficient to explain the metabolic effects of RYGB [7, 8].

The weight loss provided by RYGB directly affects the amount of body adipose tissue. Identifying adipose tissue as a metabolically active tissue in humans has positioned adipocyte as the target of many investigations. Several genes expressed mainly in adipose tissue are involved in various metabolic and endocrine functions, such as adipocyte development, lipid metabolism, glucose homeostasis and inflammatory responses [9-11]. The adipose tissue secretes several pro-inflammatory cytokines, such as interleukin-6 (IL6), tumor necrosis factor-a (TNF-a) and monocyte chemo-attracting protein (MCP-1), in addition, anti-inflammatory cytokines, such as adiponectin (ADIPOQ), which is associated with increased insulin sensitivity. [12]. Another specific adipose gene is the peroxisome proliferator-activated gamma receptor (PPAR $\Upsilon$ ) that plays a determining role in the distribution of body fat in humans [13, 14]. Another gene that is involved in the regulation of metabolism is PGC-1a (PPARycoactivator-1). This one plays a critical role in maintaining glucose, lipid, and energy homeostasis and is likely involved in pathogenic conditions such as obesity and diabetes [15].

The inflammatory process, characteristic of obesity, is linked in many levels to the endoplasmic reticulum stress (ERS). When the ER becomes stressed due to the accumulation of newly synthesized unfolded proteins, the unfolded protein response (UPR) is activated [16]. Excessive UPR signaling is associated with obesity and metabolic dysfunction $[17,18]$. One of the main monitors of the ER lumen is EIF2AK3 (Eukaryotic Translation Initiation Factor 2 Alpha Kinase 3), one of the first triggers of the ERS [19]. Moreover, other major effectors of the ERS response is ATF4 (activating transcription factor 4) [20]. ATF4 plays an important role in regulating obesity as well as glucose homeostasis in mammals [21].

In mammalian systems, Sirtuins such as SIRT1 (sirtunin 1) and SIRT3 (sirtunin 3) are NAD + proteindependent deacylases, being indispensable energy sensors, and their function is intrinsically linked to cellular metabolism [22]. Several studies have reported that caloric restriction induces the expression of the SIRT1 [23, 24] and SIRT3 [25] and that obesity can reduce the expression of SIRT1 in humans [26, 27]. There are several other nutrient sensors besides sirtuins, such as AMP-activated protein kinase (AMPK), a nutrient and energy sensor that maintains energy homeostasis [28] and general control nonderepressible 2 (GCN2), a kinase that modulates response to amino acid starvation [29], both sensors activated by caloric restriction.

Studies have proposed that oxidative stress plays an important role in the metabolic syndrome's genesis [30, 31]. Also, obesity is associated with reduced expression of several antioxidant proteins [32]. The superoxide dismutases (SOD) represent the primary cellular defense against oxidative stress. Animal studies have shown that mice with increased Sod2 expression were protected from obesity-induced insulin resistance [33]. Furthermore, Nuclear factor erythroid 2 -related factor 2 (NRF2) is considered other fundamental factor in resistance to oxidative stress [34], and its relationship to obesity has been reported in several studies $[35,36]$, NRF2 being a promising target for the treatment of obesity [30]. Thus, the functional study of adipose tissue in humans is an excellent strategy to understand in more detail the effects of RYGB.

To assess whether genetic alterations post-bariatric surgery have a dynamism that can be linked to protective effects against the development of metabolic syndrome this study aimed to determine the effects of RYGB on adipose tissue in obese non-diabetic women after 3 and 6 months compared to baseline. This approach allowed us to determine that RYGB induces significant adipose tissue changes, which may be necessary for protection against metabolic complications. 


\section{Materials and methods}

\section{Subjects and study design}

The cohort included 13 non-diabetic obese women who underwent gastric bypass surgery. The subjects were recruited using personal communication and social media attended at the Clinics Hospital of Ribeirao Preto -USP. Participants were selected from March 2018 to January 2019, and exclusion criteria included complications from the metabolic syndrome, malignancy, pregnancy and body weight over $140 \mathrm{~kg}$. None of the participants in this study were using any medication that could interfere in the glycemic control. Three analyzes were carried out, one day before surgery and 3 and 6 months after the surgical procedure. The measurements included anthropometry, blood biochemistry and abdominal adipose tissue biopsy analysis.

All procedures in this study were performed following the ethical standards as laid down in the Declaration of Helsinki. Informed consent was signed and obtained from all subjects. The study protocol was approved by the Ethics Committee of the Ribeirao Preto Medical School at the University of Sao Paulo, Brazil (protocol number CAAE: 73585317.0.0000.5440).

\section{Anthropometric assessment}

Body weight $(\mathrm{kg})$ was measured with an electronic Filizola scale of platform type with a maximum capacity of $300 \mathrm{~kg}$ and a precision of $0.1 \mathrm{~kg}$. Fat mass and percent and fat-free mass were measured using direct segmental multi-frequency bioelectrical impedance analysis (BIA 310e Bioimpedance Analyzer-Biodynamics). Height was measured using a fixed stadiometer to the nearest $0.1 \mathrm{~cm}$. Body mass index (BMI) was calculated as $\mathrm{kg} / \mathrm{m}^{2}$ accordingly. Hip and waist circumferences were measured to the nearest $0.01 \mathrm{~m}$ using a nonstretchable measuring tape (3 M).

\section{Biochemical analysis}

Blood samples were obtained after 12-h fasting. The biochemical analyzes were performed in the central laboratory of the Clinics Hospital of Ribeirao Preto. Commercial kits were used to measure insulin (IMMULITE 2000), A1C (D-10 Hemoglobin Testing System, Bio-Rad), glucose, cholesterol, triglycerides, LDL and HDL (Wiener lab CMD 800ix2).

Insulin resistance was estimated from blood samples with the homeostasis model assessment for insulin resistance (HOMA-IR), calculated using the HOMA2 Calculator software (http://www.dtu.ox.ac.uk/homac alculator/) [37].

\section{Biopsy, RNA extraction and qPCR}

Biopsy of subcutaneous adipose tissue $(80 \mathrm{mg})$ was taken after local anesthesia from 13 non-diabetic obese women after informed consent by a trained surgeon from Ribeirao Preto Medical School-USP. The first biopsy was systematically collected from the right side of the abdomen and the second biopsy from the left side of the abdomen. The adipose tissue was rapidly transported to the research laboratory. Tissue samples were rinsed in phosphate-buffered saline to remove adhering blood and after was snap-frozen in liquid nitrogen and stored at $-80^{\circ} \mathrm{C}$ until completion of the study.

Briefly, RNA was isolated from approximately $40 \mathrm{mg}$ of tissue using Trizol reagent (Life Technologies ${ }^{\circledR}$ ), following the 'manufacturer's instructions and confirmed to be free of proteins or phenol using UV spectrophotometry. The cDNA synthesis was conducted using the iScript cDNA Synthesis Kit (Bio-Rad $\left.{ }^{\circledR}\right)$ using $1 \mu \mathrm{g}$ of total RNA. The gene expression rate was then evaluated by quantitative real-time PCR (qPCR). Each reaction mixture containing $250 \mathrm{nM}$ of each primer (sense and antisense), $25 \mathrm{ng}$ of cDNA and SsoFast EvaGreen Super$\operatorname{mix}\left(\mathrm{Bio}^{-\mathrm{Rad}^{\circledR}}\right)^{\circledR}$ in a final volume of $10 \mu \mathrm{L}$ was analyzed in a CFX96 Touch $^{\mathrm{TM}}$ Real-Time PCR Detection System $\left(\operatorname{Bio}^{-\operatorname{Rad}^{\circledR}}{ }^{\circ}\right.$ under the following amplification conditions: $50{ }^{\circ} \mathrm{C}-2 \mathrm{~min}, 95^{\circ} \mathrm{C}-10 \mathrm{~min}, 40$ cycles of $95^{\circ} \mathrm{C}-15 \mathrm{~s}$, $60{ }^{\circ} \mathrm{C}-20 \mathrm{~s}$ and $72{ }^{\circ} \mathrm{C}-30 \mathrm{~s}$.

\section{Statistics}

The results are given as the mean \pm S.D. (Standard deviation) or SEM (Standard error of the mean). Statistical analyses were performed using either paired t-test or one-way repeated measures ANOVA with posthoc Tukey as appropriate. Pearson correlation coefficients were calculated to quantify the relationships between BMI changes and mRNA expression of defined target genes. Values were considered to be statistically significant when the $\mathrm{P} \leq 0.05$. The statistical analysis was performed with SAS (SAS Institute), and graph construction was performed using Graphpad Prism (Graphpad Prism 8 for Mac).

\section{Data and resource availability}

The data sets generated during and/or analyzed during the current clinical trial are available from the corresponding author upon reasonable request.

\section{Results}

\section{Participant characteristics}

Fifteen participants were invited, and thirteen participants were included in the study. We evaluated 13 obese, non-diabetic patients (mean age $37.7 \pm 8.2$ years; $100 \%$ 
women; Height $1.64 \pm 0.05 \mathrm{~m}$; BMI $42.2 \pm 4.2 \mathrm{~kg} / \mathrm{m}^{2}$ ), that underwent Roux-en-Y gastric bypass (RYGB). The clinical and biochemical characteristics of the evaluated group are summarized in Table 1.

\section{Effects of RYGB on body composition, biochemicals parameters and blood pressure}

After RYGB, we observed a significant reduction in body weight and BMI after 3 months (3 M) (-16.9\%, $\mathrm{P}<0.05 ;-14.9 \%, \mathrm{P}<0.05$ respectively) and 6 months (6 M) $(-20.5 \%, \mathrm{P}<0.01 ;-21.8 \%, \mathrm{P}<0.001$ respectively) Table 1. Waist circumference had not changed at $3 \mathrm{M}$, but after $6 \mathrm{M}$ decreased by $-12.9 \%(\mathrm{P}<0.05)$. In addition, fat mass was decreased by $-28.4 \%(\mathrm{P}<0.05)$ at $3 \mathrm{M}$ and $-34.8 \%(\mathrm{P}<0.001)$ at $6 \mathrm{M}$. However, there was no difference in lean mass Fig. 1.

Despite having a downward trend fasting glucose levels and $\mathrm{A} 1 \mathrm{C}$, did not show significant differences after RYGB, Table 1. The total cholesterol, HDL cholesterol, LDL cholesterol and triglycerides did not show significant differences after RYGB, Table 1. Fasting insulin levels did not show significant change at $3 \mathrm{M}$; however, in 6 months, there was a significant reduction of 56.1\% $(\mathrm{P}<0.05)$, Table 1.

Interestingly, we observed a significant reduction in insulin resistance at $3 \mathrm{M}(44.2 \%, \mathrm{P}<0.05)$ and at $6 \mathrm{M}$ (53.8\%, P $<0.05)$, as measured by the HOMA-IR index, Table 1 . Blood pressure was reduced at $3 \mathrm{M}(-16.9 \%$ systolic BP; $-25.4 \%$ diastolic BP, $\mathrm{P}<0.001$ for all) and $6 \mathrm{M}$ $(-16.1 \%$ systolic $\mathrm{BP} ;-23 \%$ diastolic $\mathrm{BP}, \mathrm{P}<0.001$ for all $)$, Table 1.

\section{Time course effects on expression of genes} in subcutaneous adipose tissue

To identify possible changes in adipose tissue gene expression in non-diabetic obese individuals before and after RYGB, we performed a screening of several genes on the fat biopsies. We investigated interleukin genes, genes involved in energy homeostasis, adipogenesis, mitochondrial biogenesis, ERS and amino acid

Table 1 Clinical characteristics of the study participants

\begin{tabular}{|c|c|c|c|}
\hline Characteristic & $\begin{array}{l}\text { Before surgery } \\
(n=13)\end{array}$ & $\begin{array}{l}\text { After } 3 \text { months } \\
(n=13)\end{array}$ & $\begin{array}{l}\text { After } 6 \text { months } \\
(n=13)\end{array}$ \\
\hline BMI $\left(\mathrm{kg} / \mathrm{m}^{2}\right)$ & $42.2 \pm 4.2$ & $35.9 \pm 4.7^{*}$ & $33.0 \pm 2.9^{\# \# \#}$ \\
\hline Body weight (kg) & $113.4 \pm 14.7$ & $94.2 \pm 13.9^{*}$ & $90.1 \pm 12.4^{\# \#}$ \\
\hline Waist circumference $(\mathrm{cm})$ & $123.2 \pm 12.0$ & $107.8 \pm 7.7$ & $107.2 \pm 13.7^{\#}$ \\
\hline Fat mass (kg) & $52.8 \pm 9.3$ & $37.8 \pm 9.1^{*}$ & $34.4 \pm 7.1^{\# \# \#}$ \\
\hline Lean mass (kg) & $61.0 \pm 5.9$ & $56.4 \pm 5.2$ & $55.7 \pm 6.1$ \\
\hline Fasting glucose (mg/dL) & $97.5 \pm 25.1$ & $87.0 \pm 19.2$ & $82.5 \pm 11.6$ \\
\hline $\mathrm{A} 1 \mathrm{C}(\%)$ & $5.4 \pm 0.7$ & $5.2 \pm 0.5$ & $5.1 \pm 0.4$ \\
\hline Cholesterol (mg/dL) & $165 \pm 20.5$ & $155.8 \pm 27.1$ & $160.9 \pm 24.1$ \\
\hline HDL cholesterol (mg/dL) & $39.0 \pm 9.5$ & $39.1 \pm 10.6$ & $42.0 \pm 10.2$ \\
\hline LDL cholesterol (mg/dL) & $105.7 \pm 20.3$ & $105.3 \pm 20.1$ & $100.4 \pm 16.5$ \\
\hline Triglycerides (mg/dL) & $121.5 \pm 67.0$ & $86.5 \pm 36.2$ & $91.9 \pm 40.1$ \\
\hline Insulin (mU/L) & $17.1 \pm 7.7$ & $9.0 \pm 5.0$ & $7.5 \pm 4.4^{\#}$ \\
\hline HOMA-IR & $2.0 \pm 1.0$ & $1.1 \pm 0.6^{*}$ & $0.9 \pm 0.5^{\#}$ \\
\hline Systolic BP (mmHg) & $136 \pm 9.6$ & $113 \pm 5.4^{* * *}$ & $114 \pm 7.5^{\# \# \#}$ \\
\hline Diastolic BP (mmHg) & $102 \pm 6.8$ & $76 \pm 5.4^{* * *}$ & $78.5 \pm 6.4^{\# \# \#}$ \\
\hline$\%$ of weight loss & NA & $-17 \%$ & $-20.50 \%$ \\
\hline$\%$ blood glucose reduction & NA & $-12.90 \%$ & $-17.50 \%$ \\
\hline$\%$ Cholesterol reduction & NA & $-5.50 \%$ & $-2.50 \%$ \\
\hline \% Triglycerides reduction & NA & $-30.90 \%$ & $-26.60 \%$ \\
\hline$\%$ LDL reduction & NA & $-0.40 \%$ & $-5.00 \%$ \\
\hline \% HDL change & NA & $-0.25 \%$ & $7.40 \%$ \\
\hline
\end{tabular}

Values are given as mean \pm SD. One-way ANOVA, post-test Tukey

$B M I$ body mass index, $A 1 C$ hemoglobin $A 1 C, H D L$ high-density lipoprotein, $L D L$ low-density lipoprotein, HOMA-IR homeostatic model assessment-insulin resistance; NA not applicable

${ }^{*}, \#, \$ p<0.05 ; *$ *\#\#,\$\$ $\mathrm{p}<0.01 ; * * * \# \#, \$ \$ \$ p<0.001$

* Baseline vs. 3 months

\# Baseline vs. 6 months

\$ 6 months vs. 3 months 

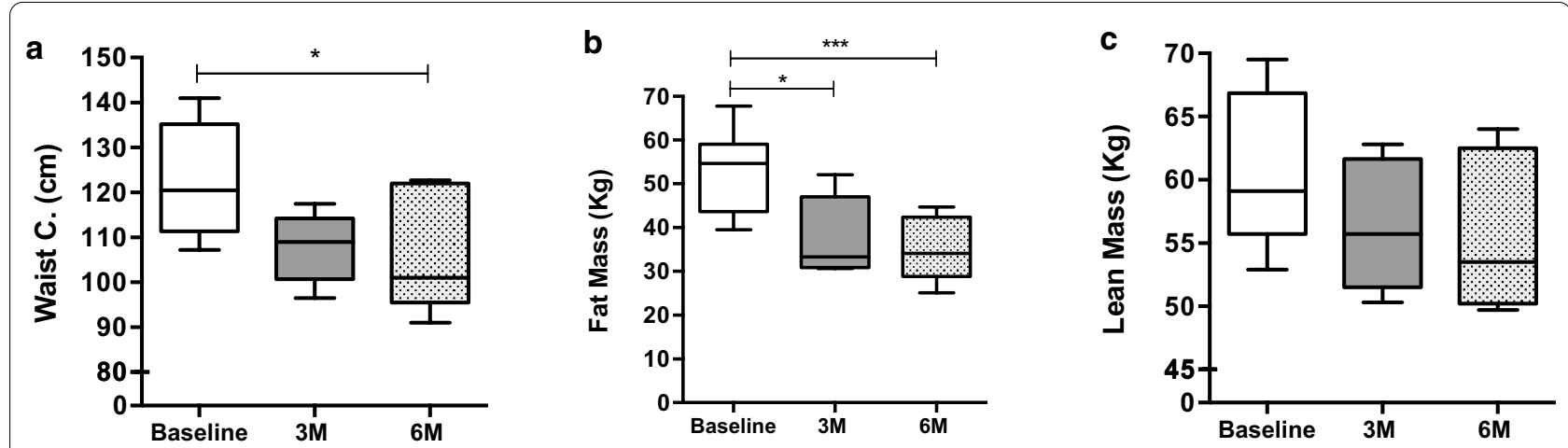

Fig. 1 Anthropometric and body composition trajectories at baseline, 3 and 6 months after RYGB. a Waist circumference. b Fat mass. $\mathbf{c}$ Lean Mass. Significance determined by one-way ANOVA and Tukey post hoc test. Data are presented in box plot. $N=13$ participants. ${ }^{*} p<0.05,{ }^{* * *} p<0.001$

metabolism, summarized in Additional file 1: Table S1. Below we report the difference in the gene expression fold change between each time point evaluated.

Three months $(3 \mathrm{M})$ after RYGB was long enough to cause a decrease in the expression levels of IL6 (Interleukin 6) $(-1.25 \pm 0.4, \quad \mathrm{P}=0.0175)$ and $M C P 1$ (monocyte chemoattractant protein 1) $(-1.90 \pm 0.4$, $\mathrm{P}=0.0008$ ) while a decrease in the expression of TNF- $a$ (Tumor necrosis factor a) was observed only after $6 \mathrm{M}$ $(-2.25 \pm 0.4, \mathrm{P}=0.0001)$ in adipose tissue, Fig. $2 \mathrm{a}$.

Additionally, we observed an increase in $A D I P O Q$ (adiponectin) expression after $3 \mathrm{M}(1.91 \pm 0.5, \mathrm{P}=0.0051)$ and a more pronounced increase after $6 \mathrm{M}(2.70 \pm 0.4$, $\mathrm{P}<0.0001$ ). Similarly, levels of PGC1a (PPAR $\gamma$ coactivator-1) was increased after $3 \mathrm{M}(1.53 \pm 0.4, \mathrm{P}<0.0039)$ and $6 \mathrm{M}(1.11 \pm 0.3, \mathrm{P}=0.0096)$ of RYGB, Fig. $2 \mathrm{~b}$. In contrast, mRNA levels of PPAR $\Upsilon$ (Peroxisome proliferator-activated receptor gamma) were reduced after $3 \mathrm{M}(-1.15 \pm 0.2, \mathrm{P}<0.0001)$ and $6 \mathrm{M}(-0.64 \pm 0.2$, $\mathrm{P}=0.0127)$, Fig. 2b.

Next, we examined the subcutaneous adipose tissue expression of genes involved in the ERS. EIF2AK3 (Eukaryotic Translation Initiation Factor 2 Alpha Kinase 3) was decreased at $3 \mathrm{M}(-2.51 \pm 0.5 ; \mathrm{P}=0.0001)$ and $6 \mathrm{M}(-2.50 \pm 0.4 ; \mathrm{P}<0.0001)$. Also, the mRNA levels of ATF4 (Activating Transcription Factor 4) was increased after $3 \mathrm{M}(1.70 \pm 0.4 ; \mathrm{P}=0.0017)$ and remained increased after $6 \mathrm{M}(1.41 \pm 0.4 ; \mathrm{P}=0.0051)$. Notably, we found that CARL (Calreticulin) expression was significant decreased at $3 \mathrm{M}(-4.08 \pm 0.4 ; \mathrm{P}<0.0001)$ and $6 \mathrm{M}(-2.59 \pm 0.4$; $\mathrm{P}<0.0001)$ after RYGB, Fig. 2c. The mRNA expression of other ERS-related genes did not show significant differences.

We also tested several genes related to the cellular response to oxidative stress and sensor of cellular energy homeostasis and amino acid concentration. In general, at $3 \mathrm{M}$ after RYGB, increased expression of SIRT1
$(2.03 \pm 0.4 ; \mathrm{P}<0.0002)$ and SIRT3 $(1.33 \pm 0.5 ; \mathrm{P}=0.0177)$. At $6 \mathrm{M}$, the mRNA expression of SIRT1 and SIRT3 remained increased compared to the baseline $(1.73 \pm 0.3$, $\mathrm{P}=0.0002 ; 1.09 \pm 0.4, \mathrm{P}=0.0205$, respectively). Moreover, compared with baseline, the expression of $A M P K$, was higher at $3 \mathrm{M}(2.27 \pm 0.3 ; \mathrm{P}<0.001)$ and $6 \mathrm{M}$ $(1.58 \pm 0.3 ; \mathrm{P}=0.0001)$ after RYGB. Finally, we verify that GCN2 mRNA levels was increased after $3 \mathrm{M}(1.73 \pm 0.2$; $\mathrm{P}<0.001)$ and $6 \mathrm{M}(1.41 \pm 0.1 ; \mathrm{P}<0.001)$, Fig. $2 \mathrm{~d}$.

We sought to determine whether RYGB could induce changes in gene expression related to oxidative stress directly in adipose tissue. Notably, we found that NRF2 expression was increased at $3 \mathrm{M}(2.49 \pm 0.4 ; \mathrm{P}<0.001)$ and $6 \mathrm{M}(1.76 \pm 0.3 ; \mathrm{P}=0.0002)$ compared to baseline. In addition, $S O D 2$ expression was increased in adipose tissue after $3 \mathrm{M}(0.75 \pm 0.2 ; \mathrm{P}=0.0161)$. However, we found no differences in expression at SOD1 and SOD3 in adipose tissue after RYGB, Fig. 2e. These data demonstrate the genetic dynamism of adipose tissue post-RYGB.

\section{BMI is positively correlated with PGC1a, SIRT1, AMPK and Adiponectin expression in human adipose tissues} We performed correlation analysis between gene expression in adipose tissue samples and the biochemical and anthropometric variables to address possible associations before and after RYGB.

Interestingly, we noted that after $3 \mathrm{M}$, the expression of PGC1a, SIRT1, and AMPK was positively correlated with the BMI changes in the same period (Pearson's correlation $\mathrm{r}=0.961, \mathrm{P}=0.009 ; \mathrm{r}=0.958, \mathrm{P}=0.010 ; \mathrm{r}=0.947$, $\mathrm{P}=0.014$ respectively), Table 2 . Similar patterns of significant correlations were found between the gene expression of $A D I P O Q$ and SIRT1 after $6 \mathrm{M}$ of RYGB and changes in BMI at $6 \mathrm{M}(\mathrm{r}=0.950, \mathrm{P}=0.001 ; \mathrm{r}=0.844$, $\mathrm{P}=0.016$ respectively), Table 2 . These data collectively suggest that the relationship between the expression of genes related to the control of energy homeostasis and 


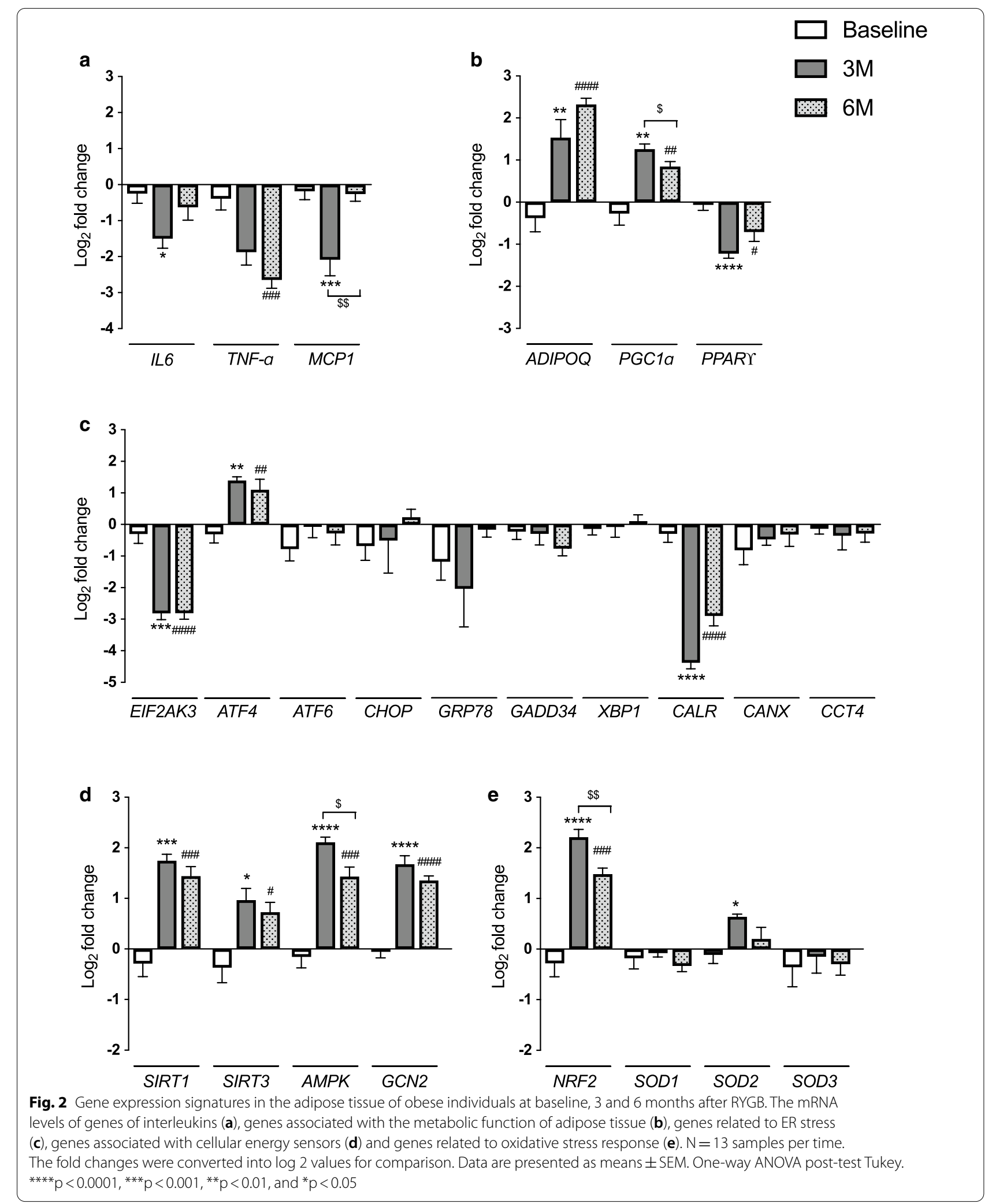


Table 2 Correlations between BMI changes and delta of gene expression in adipose tissue at 3 and 6 months after RYGB

\begin{tabular}{|c|c|c|c|c|c|}
\hline & \multicolumn{2}{|c|}{ Correlation statistics } & & \multicolumn{2}{|c|}{ Correlation statistics } \\
\hline & Pearson's r & $p$ value & & Pearson's r & $p$ value \\
\hline 3 months & & & 6 months & & \\
\hline $1 L 6$ & 0.362 & 0.548 & $1 L 6$ & -0.305 & 0.5046 \\
\hline TNFa & 0.344 & 0.570 & $T N F a$ & -0.555 & 0.1954 \\
\hline MCP1 & 0.497 & 0.394 & MCP1 & 0.183 & 0.6942 \\
\hline$A D I P O Q$ & -0.066 & 0.915 & $A D I P O Q$ & 0.950 & 0.0010 \\
\hline PGC1a & 0.961 & 0.009 & PGCla & 0.386 & 0.3915 \\
\hline PPARY & 0.384 & 0.523 & PPARY & 0.591 & 0.1623 \\
\hline EIF2AK3 & 0.511 & 0.379 & EIF2AK3 & 0.165 & 0.7233 \\
\hline ATF4 & 0.648 & 0.237 & ATF4 & -0.373 & 0.4097 \\
\hline ATF6 & 0.410 & 0.492 & ATF6 & 0.677 & 0.0945 \\
\hline $\mathrm{CHOP}$ & 0.254 & 0.680 & CHOP & -0.286 & 0.5332 \\
\hline GRP78 & 0.261 & 0.671 & GRP78 & 0.46 & 0.2987 \\
\hline GADD34 & -0.554 & 0.332 & GADD34 & -0.05 & 0.9141 \\
\hline$X B P 1$ & -0.609 & 0.275 & $X B P 1$ & 0.232 & 0.6164 \\
\hline CALR & 0.004 & 0.994 & CALR & 0.416 & 0.3523 \\
\hline CANX & 0.490 & 0.401 & CANX & 0.743 & 0.0554 \\
\hline CCT4 & 0.637 & 0.247 & CCT4 & 0.272 & 0.5539 \\
\hline SIRT1 & 0.958 & 0.010 & SIRT1 & 0.844 & 0.0169 \\
\hline SIRT3 & 0.407 & 0.496 & SIRT3 & 0.489 & 0.2646 \\
\hline$A M P K$ & 0.947 & 0.015 & AMPK & 0.692 & 0.0846 \\
\hline GCN2 & -0.511 & 0.379 & GCN2 & 0.278 & 0.5459 \\
\hline NRF2 & 0.127 & 0.839 & NRF2 & -0.014 & 0.9757 \\
\hline SOD1 & -0.342 & 0.573 & SOD1 & -0.527 & 0.2232 \\
\hline SOD2 & -0.710 & 0.178 & SOD2 & -0.112 & 0.8102 \\
\hline SOD3 & -0.466 & 0.428 & SOD3 & 0.105 & 0.8227 \\
\hline
\end{tabular}

IL6: Interleukin 6; TNF-a: Tumor necrosis factor-a; MCP-1: Monocyte

chemoattractant protein-1; PGC1a: Peroxisome proliferator-activated receptor gamma coactivator 1-alpha; PPAR 1 : Peroxisome proliferator activated receptor gamma; EIF2AK3: Eukaryotic translation initiation factor 2 alpha kinase 3;

ATF4: Activating Transcription Factor 4; ATF6: Activating Transcription Factor 6; CHOP: C/EBP homologous protein; GRP78: Heat shock protein family A (Hsp70) member 5; GADD34: growth arrest and DNA damage-inducible protein; XBP1:

X-box binding protein 1; CARL: Calreticulin; CANX: Calnexin; CCT4: Chaperonin Containing TCP1 Subunit 4; SIRT1: Sirtuin 1; SIRT3: Sirtuin 3; AMPK: AMPactivated protein kinase; GCN2: General control nonderepressible 2; NRF2: Nuclear factor erythroid 2-related factor 2; SOD1: Superoxide dismutase 1; SOD2: Superoxide dismutase 2, SOD3: Superoxide dismutase 3

mitochondrial biogenesis may be dependent on postRYGB time dynamics in adipose tissue.

\section{Discussion}

This study investigated the impact of RYGB on the dynamic of gene expression in adipose tissue in nondiabetic obese humans. Our study provides interesting evidence of the acute effect of RYGB on human adipose tissue at the molecular level, we also, describe the associations of gene expression with metabolic improvement provided by the surgical procedure.
As described in the literature, our study confirms the pronounced effect of RYGB on BMI and fat mass reduction after 3-6 months $[38,39]$. As expected, this was accompanied by metabolic improvements such as decreased fasting insulin levels, HOMA-IR and blood pressure. Our findings agree with some authors that described a rapid improvement in insulin resistance, mainly reducing insulin levels after RYGB [40, 41]. Our participants also had a 65\% improvement in HOMA-IR after 6 months, very similar to the results reported by Rao and colleagues after the same period [42]. Previous studies have also demonstrated that bariatric surgery markedly reduces the risk of cardiovascular disease, including the decrease in hypertension associated with obesity [38, 43, 44]. We confirm earlier findings, showing that in non-diabetic and mildly hypertensive obese women, systolic and diastolic blood pressure decreased significantly after 3 and 6 months of RYGB. These observations are of interest because they demonstrate the same effects of metabolic improvement, characteristic of RYGB, in individuals with class III obesity and hypertension but no diabetes mellitus.

We also performed an extensive analysis of gene expression signatures in the adipose tissue of obese individuals before and 3 and 6 months after RYGB. Molecular analysis revealed that RYGB decreased the expression of genes involved in the inflammatory process, mainly IL6 and $M C P 1$, after $3 \mathrm{M}$ and TNF-a after $6 \mathrm{M}$, concomitant to an increased expression $A D I P O Q$ at both times, an anti-inflammatory adipokine. Obesity is a pro-inflammatory condition in which adipocytes and immune cells residing in adipose tissue contribute to the increase in circulating levels of pro-inflammatory cytokines [45]. Inflammatory markers such as $I L 6, M C P 1$ and TNF- $a$ are secreted by adipocytes and are directly associated with high BMI, obesity and insulin resistance [46-48]. ADI$P O Q$ was positively correlated with BMI [49] and also has an important insulin-sensitizing effect [50]. Our findings showed that there are genetic changes of $I L 6, M C P 1$ and TNF- $a$ in adipose tissue in the acute phase after RYGB, a result that was not observed in a study that evaluated the gene expression of these interleukins after 1 year [51]. However, our findings agree with a previous study that reported increased adiponectin expression after $6 \mathrm{M}$ [52]. Given that inflammatory pathways can exert opposing or redundant functions, the decreased expression of genes encoding adipokines at adipose tissue, may be responsible for the improved metabolic and decreased insulin resistance seen at RYGB.

In our study, specific adipose genes such as PPAR $\Upsilon$ and $P G C-1 a$ had a significant alteration in gene expression after 3 and $6 \mathrm{M}$. Changes in adipose tissue metabolism's main regulators have significant implications for energy 
metabolism and the response to insulin sensitivity. The reduction in PPAR $\Upsilon$ expression observed in our study is in harmony with other authors who showed a decrease in PPAR $\Upsilon$ expression after bariatric surgery [53, 54]. The negative regulation of PPAR $\Upsilon$ in adipose tissue after RYGB suggests adipogenesis inhibition and an improvement in insulin sensitivity [55]. Other adipogenesis related genes such as $P G C$ - $1 a$ was significantly upregulated post-RYGB. Similar changes have been reported during weight loss after RYGB, which was associated with the improvement of insulin sensitivity [56]. Our findings suggest that acutely after RYGB, adipose tissue has a decrease in PPAR $\Upsilon$ adipose activity, while PGC-1a shows upregulation and these changes was observed together with an improvement in insulin sensitivity.

Activation of ERS is known to exercise profound effects on various metabolic processes. We found that markers of ERS such as EIF2AK3 and CALR significantly decreased gene expression after RYGB. Like showed by Mosinski et al., in animal model, PERK (EIF2AK3) gene expression was reduced after RYGB [57]. Gregor et al., reported a decrease in ERS in human samples of adipose tissue and liver [58]. However, they did not specifically study the gene expression of EIF2AK3. In contrast to Gregor et al. 's findings, we did not see any change in the GRP78 gene expression after $3 \mathrm{M}$ and $6 \mathrm{M}$ in our study.

Interestingly, we found that CARL expression was decreased after RYGB. Calreticulin is found in several parts of the cell, including the ER. In addition, calreticulin plays a role in ensuring the proper folding of newly formed proteins in the ER [59]. We believe that we are the first group to describe the effects of RYGB under the expression of calreticulin in adipose tissue because no data are found in the literature to draw a parallel to our results. Together, these data demonstrate a significant regulation of ER stress in weight loss provided by RYGB and a possible link with the reduction of inflammation and metabolic improvement [16].

Sirtuins regulate the aging process and are present in critical tissues such as adipose tissue to mediate physiological adaptability to diets [22]. Here we showed that expression of SIRT1 and SIRT3 were enhanced in adipose tissue post-RYGB. In line with our observations, Moschen et al., demonstrated that SIRT1 and SIRT3 mRNA expression was higher in subcutaneous adipose tissue 6 months after laparoscopic adjustable gastric banding surgery. In addition, Pedersen et al. reported increased expression of SIRT1 in adipose tissue biopsies from human volunteers submitted to 6 days of total fasting [26]. Our results supported by data in the available literature suggest that Sirtuins may play an important role in the beneficial effects of calorie restriction provided by the acute phase of RYGB.
AMPK is a nutrient and energy sensor that maintains energy homeostasis [60]. We have shown here that $A M P K$ expression increased after $3 \mathrm{M}$ and $6 \mathrm{M}$ of RYGB. Our results are consistent with previous studies showing an association between improved AMPK activity and insulin sensitivity in individuals after RYGB weight-loss surgery [61]. GCN2 was first discovered as a critical sensor of amino acid depletion [62]. In amino acid deprivation, GCN2 phosphorylates eIF $2 \alpha$, leading to the inhibition of general protein synthesis while increasing the translation of specific transcription factors, such as ATF4 [63]. Consistently we found that GCN2 mRNA expression was markedly increased after $3 \mathrm{M}$ and $6 \mathrm{M}$ of RYGB and an increased expression of ATF4. This outcome suggests that the acute effects induced by postRYGB calorie restriction consistently act to increase the gene expression of classic nutritional sensors like AMPK but also GCN2, a specific amino acid sensor.

We also examined the activity of oxidative stress markers at adipose tissue due to its association in the genesis of the metabolic syndrome [30] and obesity [31]. Here we showed an upregulation of NRF2 in adipose tissue after RYGB. NRF2 plays a critical role in adipose tissue working as a primary cellular defender against oxidative stress's cytotoxic effects [64]. Our findings agree with studies using animal model, which showed NRF2 expression was significantly increased after RYGB [65]. Furthermore, SOD2 expression, another important mediator against oxidative stress, is increased in adipose tissue after $3 \mathrm{M}$ of RYGB. Some studies indicate that caloric restriction reduces oxidative stress by activation of SOD2 [66, 67], but we have found no studies that describe a SOD2 response to the effects of RYGB. Our results revealed rapid changes in adipose tissue gene expression within $6 \mathrm{M}$ after RYGB. The current data set suggests that the acute phase of RYGB promotes a substantial metabolic change in human adipose tissue creating a potentially beneficial physiological status associated with weight loss and insulin sensitivity.

Finally, we noted a strong correlation between BMI alteration and expression of PGC1a, SIRT1, AMPK after $3 \mathrm{M}$ and $A D I P O Q$ and SIRT1 after $6 \mathrm{M}$ of RYGB. The data presented here extend the findings of the effects of RYGB on adipose tissue, providing associative evidence between decreased BMI and genes that control cellular energy homeostasis, nutritional sensors, anti-inflammatory functions and insulin sensitivity, suggesting an adaptive process in the level of gene expression as a result of caloric restriction and weight loss after the RYGB.

There are some limitations to the current study that should be mentioned. We investigated only female patients, and we had a small sample size due to difficulties in accepting and performing biopsies of adipose tissue in our patients. Also, we only had access to subcutaneous fat 
removed from the abdominal region. With that, we concentrated our analyzes on this biological material. Due to the low amount of material collected, we were only able to analyze gene expression of the adipose tissue's gene expression, not confirm our findings at the protein level. This study did not analyze or include the potential influences of the incretin system on outcomes.

\section{Conclusion}

Our study shows that RYGB has short-term effects on the dynamism of gene expression in adipose tissue in nondiabetic obese women and that these changes have the potential to modulate metabolic regulation, mainly the attenuated inflammatory response, decreased ERS, activation of genes that respond to oxidative stress and genes that inhibit adipogenesis and improve insulin sensitivity. Our discoveries of the molecular signatures for improving metabolic function after RYGB, especially under adipose tissue, may help develop new strategies to produce the same benefits as RYGB in patients not eligible for surgery.

\section{Supplementary information}

Supplementary information accompanies this paper at https://doi. org/10.1186/s13098-021-00623-w.

Additional file 1: Table S1. Gene Expression of adipose tissue 3 and 6 months post RYGB compared with Baseline.

\section{Abbreviations}

T2D: Type 2 Diabetes; RYGB: Roux-en-Y gastric bypass; IL6: Interleukin-6; TNF-a: Tumor Necrosis Factor-a; MCP-1: Monocyte Chemo-Attracting Protein 1; ADIPOQ: Adiponectin; PPAR $\Upsilon$ : Peroxisome Proliferator-Activated Gamma Receptor; PGC-1a: PPARyco-activator-1; ERS: Endoplasmic Reticulum Stress; UPR: Unfolded Protein Response; EIF2AK3: Eukaryotic Translation Initiation Factor 2 Alpha Kinase 3; CHOP: C/EBP homologous protein; GRP78: Heat shock protein family A (Hsp70) member 5; GADD34: Growth arrest and DNA damageinducible protein; XBP1: X-box binding protein 1; CARL: Calreticulin; CANX: Calnexin; CCT4: Chaperonin Containing TCP1 Subunit 4; ATF4: Activating Transcription Factor 4; SIRT1: Sirtunin 1; SIRT3: Sirtunin 3; AMPK: AMP-Activated Protein Kinase; GCN2: General Control Nonderepressible 2; SOD1: Superoxide dismutase 1; SOD2: Superoxide dismutase 2, SOD3: Superoxide dismutase 3; NRF2: Nuclear Factor Erythroid 2 -Related Factor 2; HOMA-IR: Homeostasis Model Assessment for Insulin Resistance.

\section{Acknowledgements}

The authors thank all the patients who provided the biological samples for this study.

\section{Authors' contributions}

Conceptualization, RFB and MCFF; Methodology, RFB, CW, POC and RAB; Investigation, RFB, CW and POC; Funding Acquisition, RFB and MCFF; Writing Original Draft, RFB and MCFF; Supervision, WSJ, CBN and MCFF. RFB and MCFF are the guarantors of this work and, as such, had full access to all the data in the study and takes responsibility for the integrity of the data and the accuracy of the data analysis. All authors read and approved the final manuscript.

\section{Funding}

This study was supported by Grant from the Sao Paulo research foundation (FAPESP) 2015/12133-0.

\section{Availability of data and materials}

The datasets used and/or analyzed during the current study are available from the corresponding author on reasonable request.

\section{Ethics approval and consent to participate}

The study protocol and the informed consent form were approved by the Ethics Committee of the Ribeirao Preto Medical School at the University of Sao Paulo, Brazil (protocol number CAAE: 73585317.0.0000.5440_registered on March 6, 2018).

\section{Consent for publication}

Not applicable.

\section{Competing interests}

The authors declare that they have no competing interests.

\section{Author details}

${ }^{1}$ Division of Endocrinology and Metabolism, Department of Internal Medicine, Ribeirao Preto Medical School, University of Sao Paulo (USP), Avenida Bandeirantes, 3900-Vila Monte Alegre, Ribeirao Preto, SP 14049-900, Brazil.

${ }^{2}$ Department of Surgery and Anatomy, Ribeirão Preto Medical School, University of São Paulo, Ribeirao Preto, SP, Brazil. ${ }^{3}$ Laboratory of Nutrigenomic Studies, Ribeirão Preto Medical School, University of Sao Paulo (USP), Ribeirao Preto, SP, Brazil.

Received: 17 August 2020 Accepted: 2 January 2021

Published online: 16 February 2021

\section{References}

1. Jensen MD, Ryan DH, Apovian CM, Ard JD, Comuzzie AG, Donato KA, et al 2013 AHA/ACC/TOS guideline for the management of overweight and obesity in adults: a report of the American College of Cardiology/American Heart Association Task Force on Practice Guidelines and The Obesity Society. Circulation. 2014;129:S102-38.

2. Smyth S, Heron A. Diabetes and obesity: the twin epidemics. Nat Med. 2006;12:75-80.

3. Artham SM, Lavie CJ, Milani RV, Ventura HO. Obesity and hypertension, heart failure, and coronary heart disease-risk factor, paradox, and recommendations for weight loss. Ochsner J. 2009;9:124-32.

4. Lauby-Secretan B, Scoccianti C, Loomis D, Grosse Y, Bianchini F, Straif K, et al. Body Fatness and Cancer-Viewpoint of the IARC Working Group. N Engl J Med. 2016;375:794-8.

5. Sjostrom L, Narbro K, Sjostrom CD, Karason K, Larsson B, Wedel H, et al. Effects of bariatric surgery on mortality in Swedish obese subjects. N Engl J Med. 2007;357:741-52.

6. Werling M, Fandriks L, Bjorklund P, Maleckas A, Brandberg J, Lonroth $\mathrm{H}$, et al. Long-term results of a randomized clinical trial comparing Roux-en-Y gastric bypass with vertical banded gastroplasty. Br J Surg. 2013:100:222-30.

7. Isbell JM, Tamboli RA, Hansen EN, Saliba J, Dunn JP, Phillips SE, et al. The importance of caloric restriction in the early improvements in insulin sensitivity after Roux-en-Y gastric bypass surgery. Diabetes Care. 2010;33:1438-42.

8. Jackness C, Karmally W, Febres G, Conwell IM, Ahmed L, Bessler M, et al. Very low-calorie diet mimics the early beneficial effect of Roux-en-Y gastric bypass on insulin sensitivity and beta-cell Function in type 2 diabetic patients. Diabetes. 2013;62:3027-32.

9. Feng B, Zhang T, Xu H. Human adipose dynamics and metabolic health. Ann N Y Acad Sci. 2013:1281:160-77.

10. Li B, Shin J, Lee K. Interferon-stimulated gene ISG12b1 inhibits adipogenic differentiation and mitochondrial biogenesis in 3T3-L1 cells. Endocrinology. 2009;150:1217-24.

11. Dandona P, Aljada A, Bandyopadhyay A. Inflammation: the link between insulin resistance, obesity and diabetes. Trends Immunol. 2004;25:4-7.

12. Ouchi N, Parker JL, Lugus JJ, Walsh K. Adipokines in inflammation and metabolic disease. Nat Rev Immunol. 2011:11:85-97.

13. Tontonoz P, Hu E, Devine J, Beale EG, Spiegelman BM. PPAR gamma 2 regulates adipose expression of the phosphoenolpyruvate carboxykinase gene. Mol Cell Biol. 1995;15:351-7. 
14. Tsai YS, Maeda N. PPARgamma: a critical determinant of body fat distribution in humans and mice. Trends Cardiovasc Med. 2005;15:81-5.

15. Lin J, Handschin C, Spiegelman BM. Metabolic control through the PGC-1 family of transcription coactivators. Cell Metab. 2005;1:361-70.

16. Hotamisligil GS. Endoplasmic reticulum stress and the inflammatory basis of metabolic disease. Cell. 2010;140:900-17.

17. Oyadomari S, Harding HP, Zhang Y, Oyadomari M, Ron D. Dephosphorylation of translation initiation factor Zalpha enhances glucose tolerance and attenuates hepatosteatosis in mice. Cell Metab. 2008:7:520-32.

18. Foss-Freitas MC, Ferraz RC, Monteiro LZ, Gomes PM, Iwakura R, de Freitas LCC, et al. Endoplasmic reticulum stress activation in adipose tissue induces metabolic syndrome in individuals with familial partial lipodystrophy of the Dunnigan type. Diabetol Metab Syndr. 2018;10:6.

19. Bertolotti A, Zhang Y, Hendershot LM, Harding HP, Ron D. Dynamic interaction of BiP and ER stress transducers in the unfolded-protein response. Nat Cell Biol. 2000;2:326-32.

20. Rozpedek W, Pytel D, Mucha B, Leszczynska H, Diehl JA, Majsterek I. The role of the PERK/elF2alpha/ATF4/CHOP signaling pathway in tumor progression during endoplasmic reticulum stress. Curr Mol Med. 2016:16:533-44

21. Seo J, Fortuno ES 3rd, Suh JM, Stenesen D, Tang W, Parks EJ, et al. Atf4 regulates obesity, glucose homeostasis, and energy expenditure. Diabetes. 2009;58:2565-73.

22. Chang HC, Guarente L. SIRT1 and other sirtuins in metabolism. Trends Endocrinol Metab. 2014;25:138-45.

23. Cohen HY, Miller C, Bitterman KJ, Wall NR, Hekking B, Kessler B, et al. Calorie restriction promotes mammalian cell survival by inducing the SIRT1 deacetylase. Science. 2004;305:390-2.

24. Civitarese AE, Carling S, Heilbronn LK, Hulver MH, Ukropcova B, Deutsch WA, et al. Calorie restriction increases muscle mitochondrial biogenesis in healthy humans. PLoS Med. 2007:4:e76.

25. Lombard DB, Alt FW, Cheng HL, Bunkenborg J, Streeper RS, Mostoslavsky R, et al. Mammalian Sir2 homolog SIRT3 regulates global mitochondrial lysine acetylation. Mol Cell Biol. 2007;27:8807-14.

26. Pedersen SB, Olholm J, Paulsen SK, Bennetzen MF, Richelsen B. Low Sirt1 expression, which is upregulated by fasting, in human adipose tissue from obese women. Int J Obes (Lond). 2008;32:1250-5.

27. Costa Cdos S, Hammes TO, Rohden F, Margis R, Bortolotto JW, Padoin $A V$, et al. SIRT1 transcription is decreased in visceral adipose tissue of morbidly obese patients with severe hepatic steatosis. Obes Surg. 2010;20:633-9.

28. Kahn BB, Alquier T, Carling D, Hardie DG. AMP-activated protein kinase: ancient energy gauge provides clues to modern understanding of metabolism. Cell Metab. 2005;1:15-25.

29. Sood R, Porter AC, Olsen DA, Cavener DR, Wek RC. A mammalian homologue of GCN2 protein kinase important for translational control by phosphorylation of eukaryotic initiation factor-2alpha. Genetics. 2000;154:787-801.

30. Furukawa S, Fujita T, Shimabukuro M, Iwaki M, Yamada Y, Nakajima Y, et al. Increased oxidative stress in obesity and its impact on metabolic syndrome. J Clin Invest. 2004;114:1752-61.

31. Fujita K, Nishizawa H, Funahashi T, Shimomura I, Shimabukuro M. Systemic oxidative stress is associated with visceral fat accumulation and the metabolic syndrome. Circ J. 2006;70:1437-42.

32. Tinahones FJ, Murri-Pierri M, Garrido-Sanchez L, Garcia-Almeida JM, Garcia-Serrano S, Garcia-Arnes J, et al. Oxidative stress in severely obese persons is greater in those with insulin resistance. Obesity (Silver Spring). 2009:17:240-6.

33. Hoehn KL, Salmon AB, Hohnen-Behrens C, Turner N, Hoy AJ, Maghzal GJ, et al. Insulin resistance is a cellular antioxidant defense mechanism. Proc Natl Acad Sci USA. 2009;106:17787-92.

34. Ma Q. Role of nrf2 in oxidative stress and toxicity. Annu Rev Pharmacol Toxicol. 2013;53:401-26.

35. Shin S, Wakabayashi J, Yates MS, Wakabayashi N, Dolan PM, Aja S, et al. Role of Nrf2 in prevention of high-fat diet-induced obesity by synthetic triterpenoid CDDO-imidazolide. Eur J Pharmacol. 2009;620:138-44.

36. Yu Z, Shao W, Chiang Y, Foltz W, Zhang Z, Ling W, et al. Oltipraz upregulates the nuclear factor (erythroid-derived 2)-like 2 [corrected](NRF2) antioxidant system and prevents insulin resistance and obesity induced by a high-fat diet in C57BL/6J mice. Diabetologia. 2011;54:922-34.
37. Levy JC, Matthews DR, Hermans MP. Correct homeostasis model assessment (HOMA) evaluation uses the computer program. Diabetes Care. 1998:21:2191-2.

38. Sjostrom L, Lindroos AK, Peltonen M, Torgerson J, Bouchard C, Carlsson $B$, et al. Lifestyle, diabetes, and cardiovascular risk factors 10 years after bariatric surgery. N Engl J Med. 2004;351:2683-93.

39. Hoffstedt J, Andersson DP, Eriksson Hogling D, Theorell J, Naslund E, Thorell A, et al. Long-term protective changes in adipose tissue after gastric bypass. Diabetes Care. 2017;40:77-84

40. Reed MA, Pories WJ, Chapman W, Pender J, Bowden R, Barakat H, et al. Roux-en-Y gastric bypass corrects hyperinsulinemia implications for the remission of type 2 diabetes. J Clin Endocrinol Metab. 2011;96:2525-31.

41. Kashyap SR, Daud S, Kelly KR, Gastaldelli A, Win H, Brethauer S, et al. Acute effects of gastric bypass versus gastric restrictive surgery on beta-cell function and insulinotropic hormones in severely obese patients with type 2 diabetes. Int J Obes (Lond). 2010;34:462-71.

42. Rao RS, Yanagisawa R, Kini S. Insulin resistance and bariatric surgery. Obes Rev. 2012;13:316-28.

43. Heneghan HM, Meron-Eldar S, Brethauer SA, Schauer PR, Young JB. Effect of bariatric surgery on cardiovascular risk profile. Am J Cardiol. 2011;108:1499-507.

44. Poirier P, Cornier MA, Mazzone T, Stiles S, Cummings S, Klein S, et al. Bariatric surgery and cardiovascular risk factors: a scientific statement from the American Heart Association. Circulation. 2011;123:1683-701.

45. Makki K, Froguel P, Wolowczuk I. Adipose tissue in obesity-related inflammation and insulin resistance: cells, cytokines, and chemokines. ISRN Inflamm. 2013;2013:139239.

46. Hotamisligil GS, Shargill NS, Spiegelman BM. Adipose expression of tumor necrosis factor-alpha: direct role in obesity-linked insulin resistance. Science. 1993;259:87-91.

47. Kim CS, Park HS, Kawada T, Kim JH, Lim D, Hubbard NE, et al. Circulating levels of MCP-1 and IL-8 are elevated in human obese subjects and associated with obesity-related parameters. Int J Obes (Lond). 2006:30:1347-55

48. Weisberg SP, McCann D, Desai M, Rosenbaum M, Leibel RL, Ferrante AW Jr. Obesity is associated with macrophage accumulation in adipose tissue. J Clin Invest. 2003;1 12:1796-808.

49. Arita Y, Kihara S, Ouchi N, Takahashi M, Maeda K, Miyagawa J, et al. Paradoxical decrease of an adipose-specific protein, adiponectin, in obesity. Biochem Biophys Res Commun. 1999;257:79-83.

50. Combs TP, Pajvani UB, Berg AH, Lin Y, Jelicks LA, Laplante M, et al. A transgenic mouse with a deletion in the collagenous domain of adiponectin displays elevated circulating adiponectin and improved insulin sensitivity. Endocrinology. 2004;145:367-83.

51. Viana EC, Araujo-Dasilio KL, Miguel GP, Bressan J, Lemos EM, Moyses MR, et al. Gastric bypass and sleeve gastrectomy: the same impact on IL-6 and TNF-alpha. Prosp Clin Trial Obes Surg. 2013:23:1252-61.

52. Katsogiannos $P$, Kamble PG, Boersma GJ, Karlsson FA, Lundkvist $P_{\text {, }}$ Sundbom $M$, et al. Early changes in adipose tissue morphology, gene expression, and metabolism after RYGB in patients with obesity and T2D. J Clin Endocrinol Metab. 2019;104:2601-13.

53. Jahansouz C, Xu H, Hertzel AV, Kizy S, Steen KA, Foncea R, et al. Partitioning of adipose lipid metabolism by altered expression and function of PPAR isoforms after bariatric surgery. Int J Obes (Lond). 2018;42:139-46.

54. Jurets A, Itariu BK, Keindl M, Prager G, Langer F, Grablowitz V, et al. Upregulated TNF expression 1 year after bariatric surgery reflects a cachexia-like state in subcutaneous adipose tissue. Obes Surg. 2017;27:1514-23.

55. Ahmadian M, Suh JM, Hah N, Liddle C, Atkins AR, Downes M, et al. PPARgamma signaling and metabolism: the good, the bad and the future. Nat Med. 2013;19:557-66.

56. Gastaldi G, Russell A, Golay A, Giacobino JP, Habicht F, Barthassat V, et al. Upregulation of peroxisome proliferator-activated receptor gamma coactivator gene (PGC1A) during weight loss is related to insulin sensitivity but not to energy expenditure. Diabetologia. 2007;50:2348-55.

57. Mosinski JD, Pagadala MR, Mulya A, Huang H, Dan O, Shimizu H, et al. Gastric bypass surgery is protective from high-fat diet-induced non-alcoholic fatty liver disease and hepatic endoplasmic reticulum stress. Acta Physiol (Oxf). 2016;217:141-51.

58. Gregor MF, Yang L, Fabbrini E, Mohammed BS, Eagon JC, Hotamisligil GS, et al. Endoplasmic reticulum stress is reduced in tissues of obese subjects after weight loss. Diabetes. 2009;58:693-700. 
59. Gold LI, Eggleton P, Sweetwyne MT, Van Duyn LB, Greives MR, Naylor SM, et al. Calreticulin: non-endoplasmic reticulum functions in physiology and disease. FASEB J. 2010;24:665-83.

60. Moschen AR, Wieser V, Gerner RR, Bichler A, Enrich B, Moser P, et al. Adipose tissue and liver expression of SIRT1, 3, and 6 increase after extensive weight loss in morbid obesity. J Hepatol. 2013;59:1315-22.

61. Hardie DG, Ross FA, Hawley SA. AMPK: a nutrient and energy sensor that maintains energy homeostasis. Nat Rev Mol Cell Biol. 2012;13:251-62.

62. Xu XJ, Apovian C, Hess D, Carmine B, Saha A, Ruderman N. Improved insulin sensitivity 3 months after RYGB surgery is associated with increased subcutaneous adipose tissue AMPK activity and decreased oxidative stress. Diabetes. 2015;64:3155-9.

63. Dever TE, Feng L, Wek RC, Cigan AM, Donahue TF, Hinnebusch AG. Phosphorylation of initiation factor 2 alpha by protein kinase GCN2 mediates gene-specific translational control of GCN4 in yeast. Cell. 1992;68:585-96.

64. Wek SA, Zhu S, Wek RC. The histidyl-tRNA synthetase-related sequence in the elF-2 alpha protein kinase GCN2 interacts with tRNA and is required for activation in response to starvation for different amino acids. Mol Cell Biol. 1995;15:4497-506.

65. Seo HA, Lee IK. The role of Nrf2: adipocyte differentiation, obesity, and insulin resistance. Oxid Med Cell Longev. 2013;2013:184598.

66. Peng Y, Murr MM. Roux-en-Y gastric bypass improves hepatic mitochondrial function in obese rats. Surg Obes Relat Dis. 2013;9:429-35.

67. Qiu X, Brown K, Hirschey MD, Verdin E, Chen D. Calorie restriction reduces oxidative stress by SIRT3-mediated SOD2 activation. Cell Metab. 2010;12:662-7.

68. Someya S, Yu W, Hallows WC, Xu J, Vann JM, Leeuwenburgh C, et al. Sirt3 mediates reduction of oxidative damage and prevention of age-related hearing loss under caloric restriction. Cell. 2010;143:802-12.

\section{Publisher's Note}

Springer Nature remains neutral with regard to jurisdictional claims in published maps and institutional affiliations.
Ready to submit your research? Choose BMC and benefit from:

- fast, convenient online submission

- thorough peer review by experienced researchers in your field

- rapid publication on acceptance

- support for research data, including large and complex data types

- gold Open Access which fosters wider collaboration and increased citations

- maximum visibility for your research: over $100 \mathrm{M}$ website views per year

At BMC, research is always in progress.

Learn more biomedcentral.com/submissions 